\title{
DEVELOPMENT OF TOURISM IN LATVIA: ISSUES AND POTENTIALITIES
}

\section{TŪRISMA ATTĪSTĪBA LATVIJĀ: PROBLĒMAS UN IESPĒJAS \\ Ligita MELECE}

\author{
Dr.oec., Head of Department of Quality and Environment Protection of \\ Latvian State Institute of Agrarian Economics \\ Phone: 29196063, e-mail: ligita.melece@lvaei.lv \\ Riga, Latvia \\ Mārtiṇš RUCIṆŠ
Dr.sc.ing., Assoc. Professor of Faculty of Food Technology of
Latvia University of Agriculture
Phone: 63005647, e-mail: marty@delfi.lv
Jelgava, Latvia

\begin{abstract}
Tourism is recognized as one of the most important economic sectors or industries in the world and many countries see tourism as the main instrument for economic and regional development. The paper provides a short theoretical framework for tourism and its role or impact, discussing the definition of tourism and some aspects of the tourism sector. The paper presents results of studies devoted to some issues of tourism development in Latvia. Comparison of some indicators of tourism sector's development between the Baltic States is presented. The results show that long-term development of Latvia's tourism sector is less successful than in other Baltic States, particularly in Estonia. The trends of Latvia's tourism sector development are indicative of recovery from crisis (2008-2009). Besides, opinions and impressions of foreign tourists have been analyzed with an aim to recognize the most important issues hampering the foreign tourists' flow to Latvia.
\end{abstract}

Keywords: Baltic States, development "foreign tourists, Latvia, tourism.

\section{Introduction}

Tourism is the leading industry in the service sector at the global level as well as a major provider of jobs and a significant generator of foreign exchange at the national level. Moreover, tourism has become one of the largest and the fastest growing industries in the global economy (29). Travel and tourism is the number one or two industries in most countries and will soon be the leading industry worldwide. Moreover, tourism is one of the most important economic activities in the world. The revenue generated by tourism has become a very important resource and a key factor in the balance of payment for many countries and regions and has been a major contributor to their economic growth (1). Hall $(15,4)$ argues that tourism needs greater recognition for its capacity to general economic, environmental and social benefits. For many countries tourism is seen as a main instrument for regional development, 
as it stimulates new economic activities. Tourism may have a positive economic impact on the balance of payments, on employment, on gross income and production, but it may also have negative effects, particularly on the environment (5) in other words has a multiplier effect $(13,29)$. At present global economical situation the only sector that really demonstrates a continuous upward trend has been tourism (25).

European Commission (EC) (10) indicates that tourism is a major economic activity with a broadly positive impact on the economic growth and employment in Europe. Moreover, it is declared that tourism is also an important instrument for reinforcing Europe's image in the world, projecting the values and promoting the attractions of the European model, which is the result of centuries of cultural exchanges, linguistic diversity and creativity (10). Tourism sector affects many industries of the national economy, therefore it is hard to determine the economic input of tourism into the national accounts.

The aim of research is to evaluate some development issues of tourism in Latvia and to estimate their further perspectives, which are covered due to following tasks: to study the role or impact of tourism; to compare some indicators of development of tourism between the Baltic States; and to evaluate some indicators and aspects of development of Latvia's tourism.

The principal materials used for the research are as follows: different sources of scientific publications, research papers, the EU and Latvia's legislation, and the reports of international and the EU institutions; data from databases of Central Statistical Bureau of Latvia (hereafter in this text - CSB) and Eurostat. The suitable qualitative and quantitative research methods have been used for various solutions in the process of study: analysis and synthesis; logical and abstractive constructional; data grouping and comparing; correlation and regression analysis, expert and etc.

\section{Tourism and its role}

The World Tourism Organization (6) defines tourists as people who are „travelling to and staying in places outside their usual environment for not more than one consecutive year for leisure, business and other purposes not related to the exercise of an activity remunerated from within the place visited". Uherek (33) adds that tourism is the act of travel and visiting places, independent from the purpose, which includes private travel for holiday and recreation purposes but also business travel. Egziabher (9) propose that tourism could be simply defined as a "travel and stay of a non-resident". Tourism can also be defined as a service industry with three main foci: 1) transport; 2) accommodation; 
3) services for tourists (33). Some scholars $(4,9)$ develop concept of three basic components of tourism, which are also known as 3 A's: accessibility, and accommodation and attraction (locale). In his turn, Huybers $(18,161)$ considers that tourism as a system has three basic components: tourists, geographical elements and the tourism industry. Mitchell and Ashley (22) pointed out that "using broader definitions of the tourism sector, a host of providers of recreational, leisure and shopping services, such as local guides and craft sellers may also be included".

Tourism just now is one of the world's largest industries and one of its fastest growing sectors of economy (5). Besides, tourism is characterized as a dynamic and competitive industry that requires the ability to constantly adapt to customers' changing needs and desires, such as the customer's satisfaction (35). Tourism as a global phenomenon causes consequences for populations that extend beyond the ranks of those that operate and practice it $(19,6)$. It is already evident that tourism is a complex $(14,5 ; 17)$, multidimensional phenomenon that is difficult (35), if not impossible, to define $(28,11)$. Moreover, Sharpley $(28,11)$ defines tourism as a social phenomenon manifested in the increasing mobility of people locally, nationally and internationally for a variety of purposes that are frequently, but not always leisure-driven. The tourism as a system influences, and is influenced by, a variety of 'external' factors; political, economic, technological, socio-cultural, legislative and environmental $(27,4$.).

There has been increasing dependence upon tourism as an agent of economic development (25). Within the developed world, peripheral or economically disadvantaged regions are increasingly focusing on tourism as a means of stimulating economic and social regeneration whilst, for many less developed countries, tourism has become to represent a vital ingredient of their development policies $(27,6)$. Tourism is widely considered as an effective contributor to socio-economic development, particularly in less developed countries $(31, \mathrm{i})$. The contribution of tourism to socio-economic development has been most closely related to receipts and spending in the national economy (29).

Tourism is one of the world's largest and fastest growing industries $(8,1)$, which creating jobs, bridging disparities, contributing to economic growth and bringing prosperity $(14,286)$. As one of the world's largest industries $(25 ; 26)$, tourism carries with it significant social, environmental, economic and political impacts $(15 ; 16$, i). Although tourism can provide significant economic benefits for some destinations, the image of tourism as a benign and environmentally friendly industry has often been challenged $(16,57$.). 
It is already known that innovativeness and sustainability of tourism sector is highly related with the economic progress and growth of localities and regions and affects social, cultural and economic life. Tourism is one of the economics' sectors that contribute for a large part of employment, balance payments, GDP growth, and capital investment (in direct and indirect sectors) $(8,11 ; 23,123)$. Tourism has become an extremely dynamic system. Economic globalization, fast changing customer behaviour, development of transportation and information technologies, modifications in the forms of organisations and labour, all strongly influence the industry. In this scenario the intensified marketing efforts of all tourism organisations have led to a more effective approach: the destination management approach $(1 ; 26)$. Tourism destinations behave as dynamic evolving complex systems $(15 ; 16,69 ; 17 ; 21,387)$, encompassing numerous factors and activities that are interdependent and whose relationships might be highly nonlinear (1). Traditional research in this field has looked for a linear approach: variables and relationships are monitored in order to forecast future outcomes with simplified models and to derive implications for management organizations $(1 ; 2)$. The depiction of a tourism destination as complex is quite common. Therefore, the economic and financial benefits of tourism sector on local, regional and state further development and well-being are broadly analyzed (e.g. $13 ; 22 ; 30)$. Stynes $(30,11)$ when evaluates the economic impact of tourism argues that "tourism has a variety of economic impacts. Tourists' expenditures give rise to direct and secondary (indirect and induced) effect $(8,14)$. Some researchers (e.g. $20 ; 32 ; 34,3$ ) induced effect named as 'multiplier' effect of tourism and argue that significant number of studies are devoted for this topic, which employ input-output models to explore total economic effects $(17,2)$.

An economic impact analysis of tourism activity normally focuses on changes in sales, income, and employment in a region resulting from tourism activity. On a local level, even small-scale tourist ventures under the banner of 'ecotourism' or 'community based tourism', for instance, may draw previously self-sufficient communities into the global economic system $(26,59)$.

The tourism spending like other activities has direct and secondary effects on the economy, and presents complex interaction with other activities deserving a special treatment for measuring its contribution to the global result of production and consumption $(13,29)$. Tourists contribute to sales, profits, jobs, tax revenues, and income in an area. The most direct effects occur within the primary tourism sectors accommodation, restaurants, transportation, entertainment, and retail trade etc.; and through secondary effects, tourism affects most sectors of 
the economy $(30,4)$; and causes social and environmental changes (30). For example, Mitchell and Ashley (22) provide an understanding how tourism can affect the poor by describing three pathways. First, direct effects imply labour income and other livelihood impacts through direct participation as employees or entrepreneurs in the tourism sector. Second, the secondary effects entail impacts that occur through the tourism value chain in the non-tourism economy such as food and beverage, transport and other sectors and when workers in tourism spend their earnings locally. Third, dynamic effects are wider long-term impacts on the economy and society that reinforce impacts of tourism beyond the periphery of the tourism destination such as changes in pattern of growth in other economic sectors (24), exchange rate, natural resource base and decisions based on increased government tax (22, 2010: 21-25). The most significant economic and social impact of tourism is the creation of workplaces. The tourism industry has been considered as a sector with good employment creation abilities but most of the work places are only seasonal, requiring a low education level and meaning a possibility mainly for women $(16,109)$.

Economists $(8,14)$ distinguish direct, indirect and induced economic effects. The total economic impact of tourism is the sum of direct, indirect and induced effects within a region. Indirect and induced effects are sometimes collectively called secondary effects. Tourism is a service sector with a particularly complex product $(8,775 ; 32)$. In general, tourism from the supply side perspective can be seen as a whole range of individuals, businesses, organizations and places combined in some way to deliver a travel experience $(23,124)$. Distinctive features shape the demand and the supply side (Table 1 ).

Table 1

Features shaping tourism demand and supply (adapted from Ndou $(23,124)$ )

\begin{tabular}{|l|l|}
\hline \multicolumn{1}{|c|}{ Supply features } & \multicolumn{1}{c|}{ Demand features } \\
\hline Modularity & Volatility, Ambiguity, Uncertainty \\
Heterogeneity & Experiential \\
Information intensive & Global \\
Fragmentation & \\
Local & \\
\hline
\end{tabular}

Taking into account that at present the shortages exist and, in some cases, lack of statistical data and information, which is necessary for evaluation and assessment of the tourism sector and its impact, the European Parliament (11) urges the Commission to examine the need to collect statistical information and quality data in order to allow for an 
assessment of the impact of tourism on the economy, the environment and the quality of life of the inhabitants of tourist destinations.

\section{Some development issues of tourism in the Baltic States}

The economic and financial crisis, which has affected all the economies $(6 ; 10)$ worldwide, inter alia economy of Baltic States and particularly, Latvia since 2008, has had a considerable effect on demand for tourist services. Demunter and Dimitrakopoulou (7) argue that following two years of decline in 2008 and 2009, the European touristaccommodation sector continued in 2011 a recovery that started in 2010 . The total number of nights spent at hotels and similar establishments during 2011 was well above the level of 2007, the year before the crisis began to affect the tourism sector $(7,1)$. Despite Latvia being the EU member state, the comparison of different development issues between the Baltic States, done by scholars, is quite common.

Analyzing the latest years' (2005-2010) development trends of tourism in the Baltic States, the trends of number of tourists are estimated (Fig. 1). The results of estimation, presented below (Fig. 1), demonstrate that significant growth of number of tourists is observed only in Estonia $-r=92, \alpha^{9}<0.01$. The trend for increasing of the number of tourists is present in Lithuania, although it is not significant $(r=0.62$, $\alpha>0.05$ ). In Latvia an opposite trend is observed - the number of tourists has decreased, but not significantly. The coefficient of correlation and significance level respectively is $-r=-0.56, \alpha>0.05$.

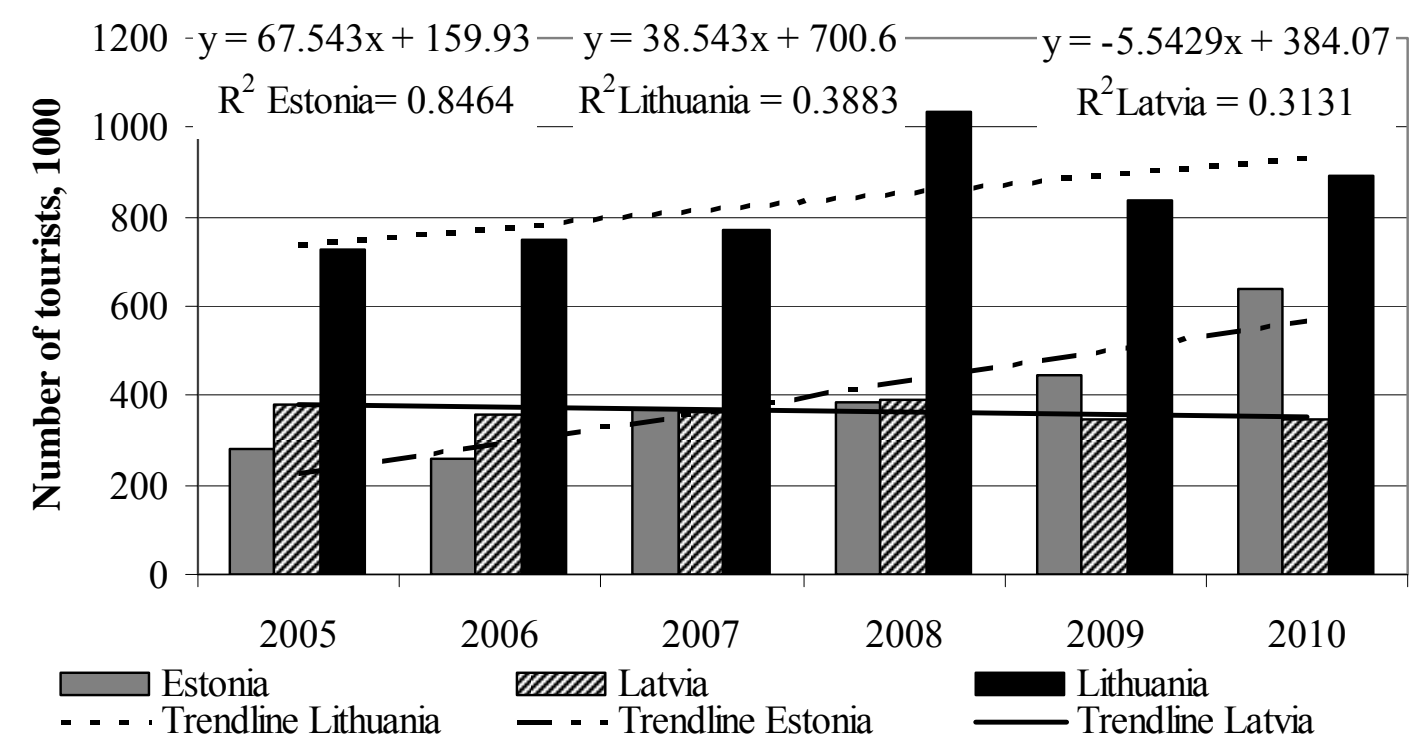

Figure 1. The trend of number (1000) of tourists in

the Baltic States, 2005-2010

(authors' calculations based on data from (12))

\footnotetext{
${ }^{9} \alpha$ - significance level or critical probability value 
Similar results are observed upon evaluation of long-term (19992010) trends of nights (1000) spent in hotels and similar establishments in the Baltic States (Fig. 2). The influence of economic and financial crisis is noticed in all the Baltic States, although the long-term trends of growth are different. In Estonia and Lithuania the growth was significant, where coefficient of correlation and significance level correspondingly is: for Estonia $-r=0.91, \alpha<0.01$, for Lithuania $-r=0.86, \alpha<0.05$. On the other hand, in Latvia some growth is observed, but it is considerably lower than in both Baltic States, and, of course, not significant $-r=0.45$, $\alpha>0.05$.

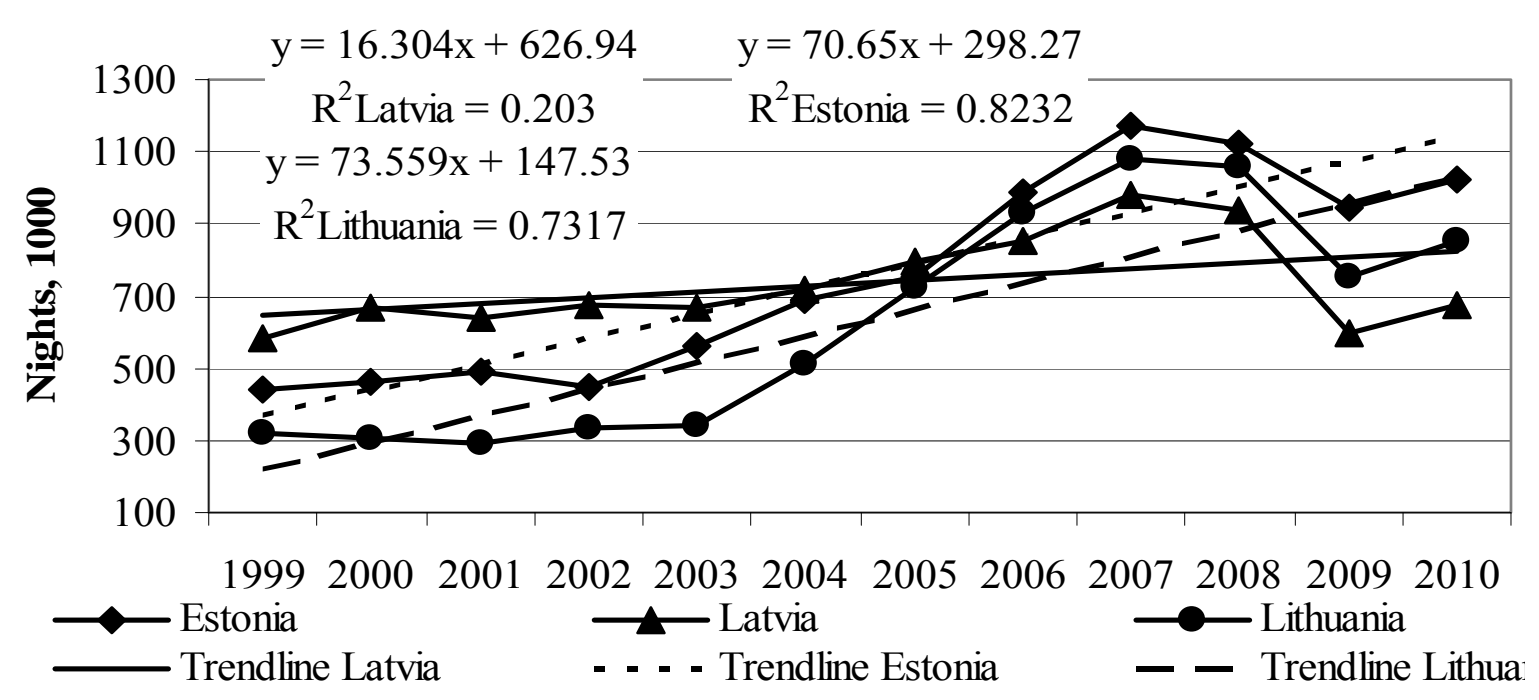

Figure 2. The trends of nights (1000) spent in hotels and similar establishments in the Baltic States, 1999-2010 (authors' calculations based on data from (12))

Comparing changes in the number of holiday trips between 2010 and 2011 in all the Baltic States (Tab. 2), we can conclude that in 2011, two Baltic States (Latvia and Lithuania), apart from Estonia, show positive trend of all holiday trips (domestic and outbound) conversely the EU average trend. 
Table 2

Estimated percentage change in the number of all holiday trips made by residents of EU (average) and the Baltic States, 2011 compared to 2010

(based on (7))

\begin{tabular}{|c|c|c|c|}
\hline & \multicolumn{3}{|c|}{ All holiday trips } \\
\hline & Total & Domestic & Outbound \\
\hline EU & $-03 \%$ & $-0.5 \%$ & $0.1 \%$ \\
\hline Estonia (EE) & $-17.1 \%$ & $-10.5 \%$ & $24.5 \%$ \\
\hline Latvia (LV) & $8.3 \%$ & $7.4 \%$ & $11.9 \%$ \\
\hline Lithuania (LT) & $4.5 \%$ & $0.4 \%$ & $12.5 \%$ \\
\hline
\end{tabular}

Moreover, Latvia is the only Baltic State, which compared to the EU average, shows positive trend or percentage change in the number of long holidays and short holidays both domestic and outbound (Tab. 3).

As shown on Table 3, Latvia and Lithuania have positive trends, comparing with the EU average and Estonia, of residents' short term holidays in 2011, compared to 2010. However, the results or trend of increase for Latvia is higher or better than for Lithuania.

Table 3

Estimated percentage change in the number of long and short holidays made by residents of the EU (average) and the Baltic States, 2011 compared to 2010 (based on (7))

\begin{tabular}{|l|l|l|l|l|l|l|}
\hline \multirow{2}{*}{} & \multicolumn{2}{|c|}{ Long holidays (4 or more nights) } & \multicolumn{3}{c|}{ Short holidays (1 to 3 nights) } \\
\cline { 2 - 7 } & Total & Domestic & Outbound & \multicolumn{1}{c|}{ Total } & Domestic & Outbound \\
\hline EU & $0.9 \%$ & $0.5 \%$ & $1.7 \%$ & $-1.4 \%$ & $-1.0 \%$ & $-5.0 \%$ \\
\hline EE & $-2.3 \%$ & $-7.4 \%$ & $0.0 \%$ & $-22.7 \%$ & $-23.0 \%$ & $-21.4 \%$ \\
\hline LV & $11.7 \%$ & $18.6 \%$ & $8.0 \%$ & $7.4 \%$ & $6.2 \%$ & $19.8 \%$ \\
\hline LT & $12.8 \%$ & $7.3 \%$ & $15.7 \%$ & $0.3 \%$ & $-1.1 \%$ & $6.7 \%$ \\
\hline
\end{tabular}

\section{Development issues and perspectives of tourism in Latvia}

Assessment of development of tourism development and its impact on Latvia's economy has been made, using available data from databases of statistical agencies on the Latvian (CSB) and the EU (Eurostat) level. Unfortunately, the data obtainable in these databases are inaccurate and outdated, in other words, data are old. It is important to evaluate the impact of tourism on Latvia's economy, the share of tourism expenditures in import and export of goods and services and its trend. Estimating the dynamics or trend of share of inbound tourists' 
expenditures in export of goods and services and trend of share of outbound tourists' expenditures in import of goods and services, the results show that both share of outbound or import and share inbound or export has decreased significantly (Fig. 3). Nevertheless, the growth of inbound share or export of expenditures is greater $-r=0.91, \alpha<0.01$, comparing with outbound share or import expenditure $-r=0.87$, $\alpha<0.05$.

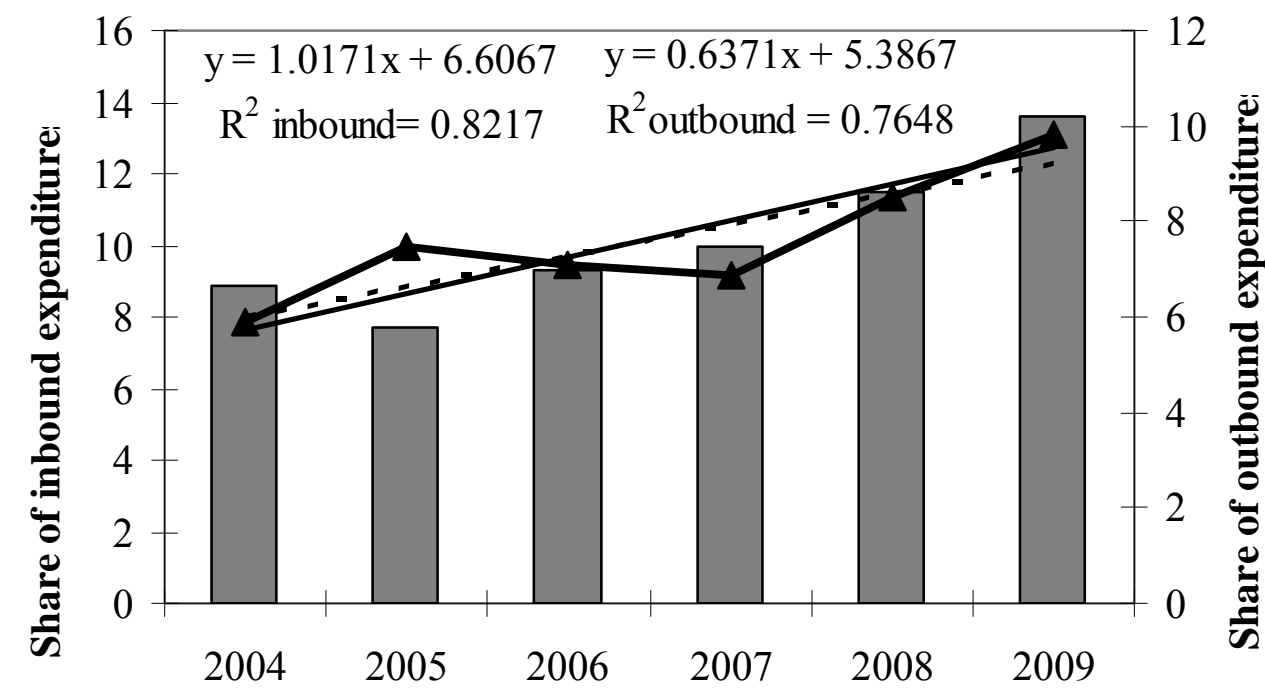

Figure 3. The trend of share (per cent) of inbound tourists' expenditures in the export of goods and services and of share (per cent) of outbound tourists' expenditures in the import of goods and services in Latvia, 2004-2009

(authors' calculations based on data from (3))

Accessing the trends of important indicators: average daily expenditure per traveller (lats) and average length of trip (visitor nights) during the period from 2004 to 2010 in Latvia, the results show two opposite trends (Fig. 4). The trend of average length of trip of foreign tourists in Latvia is negative. The period of tourists staying decrease substantially $-r=-0.96, \alpha<0.01$. On the other hand, average daily expenditure in lats of foreign tourists has increased significantly $r=0.97, \alpha<0.01$. 


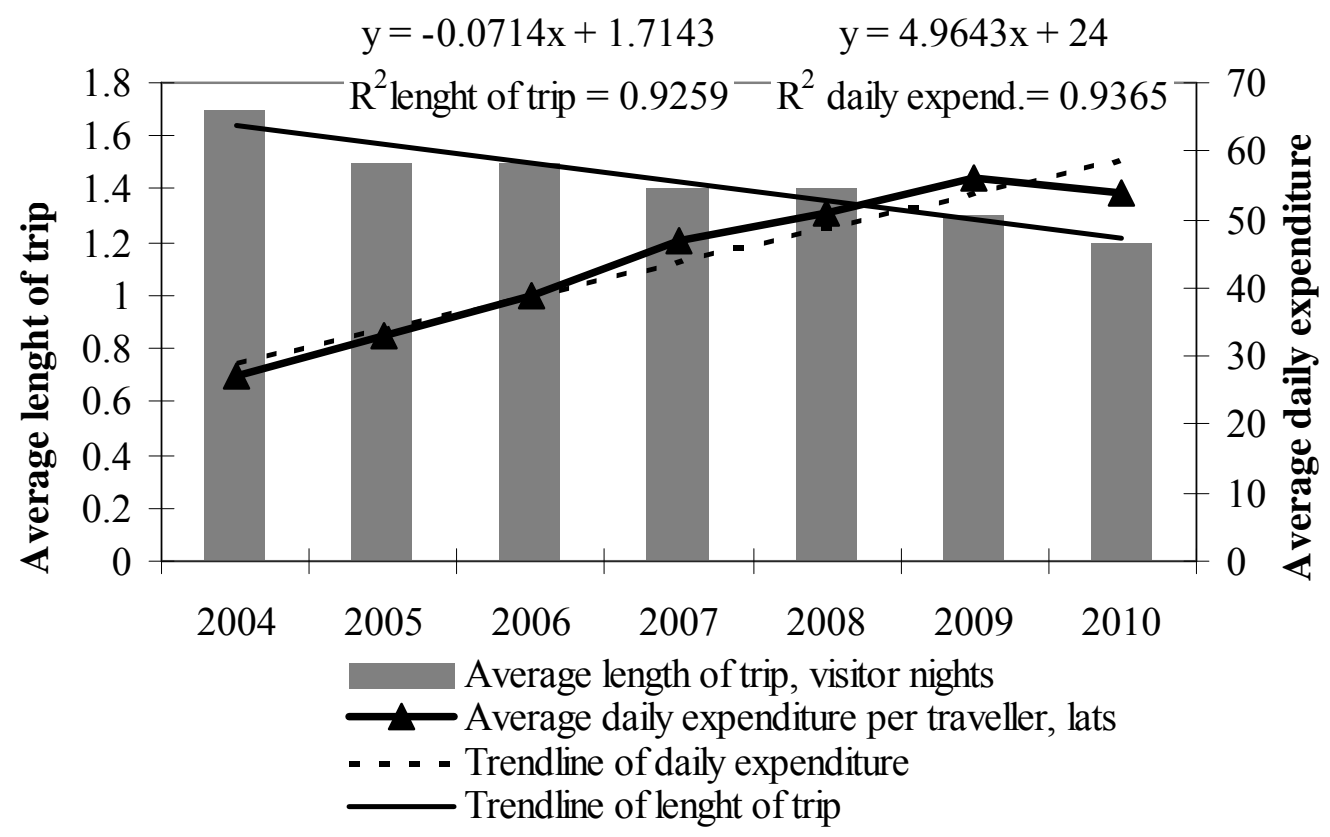

Figure 4 . The trends of average daily expenditure per traveller (lats) and average length of trip in Latvia, 2004-2010

(authors' calculations based on data from (3))

The results of estimation of dynamics or trend of total number of foreign or overseas travellers or tourists and total expenditure in Latvia (2004-2010) show that both indicators have increased (Fig. 5). The number of tourists has increased, although not significantly, $r=0.78$, $\alpha>0.05$. The total amount of expenditures of travellers has increased significantly $-r=0.84, \alpha<0.05$.

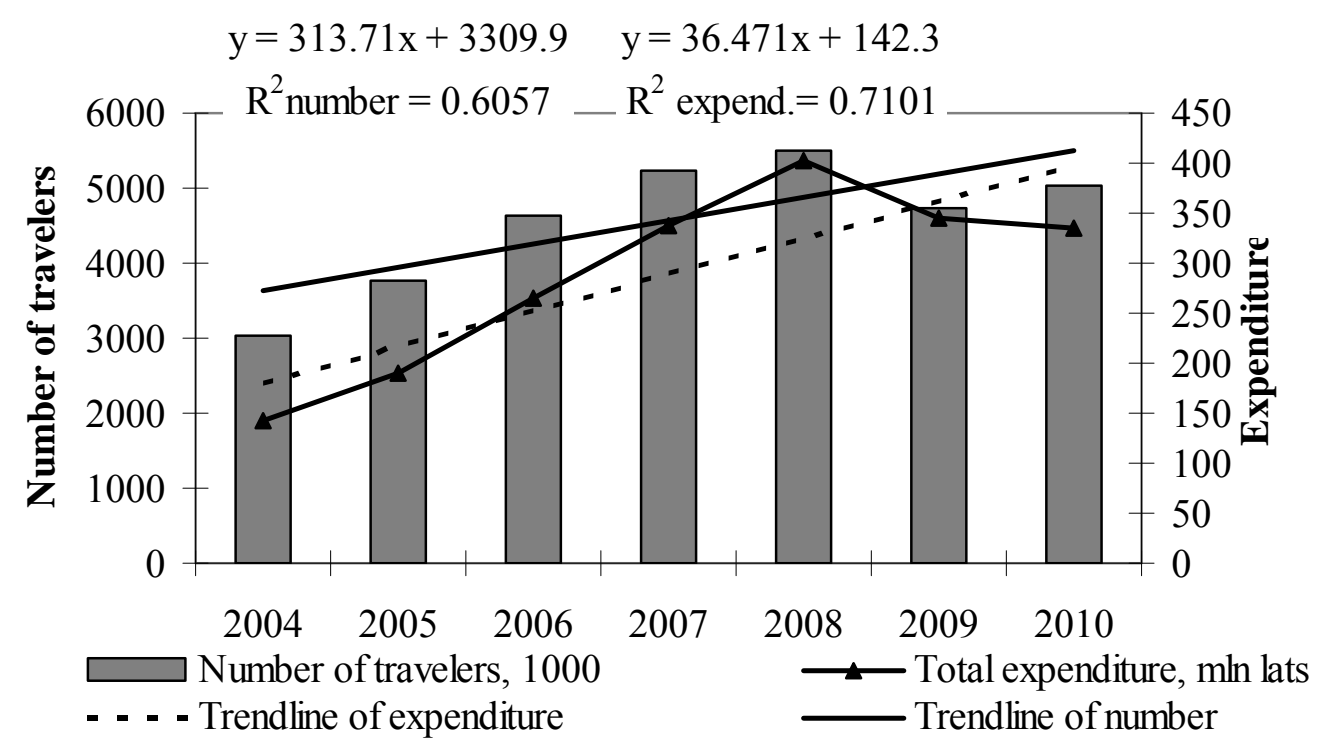

Figure 5. The trend of total number of foreign travellers (1000) and expenditure (million lats) of foreign tourists in Latvia, 2004-2010 (authors' calculations based on data from (3)) 
Looking on the tourist arrivals (most recent) in Latvia by country, we can see that tourists arrive mainly from the following countries: Russian Federation, Lithuania, Sweden, Estonia, Germany and Finland (Fig. 6). In our opinion, establishing new initiatives on governmental, municipal and enterprise level, these data should be taken into consideration, for example, when discussing the languages used for tourist information and waypoints, information and meals in catering service etc.

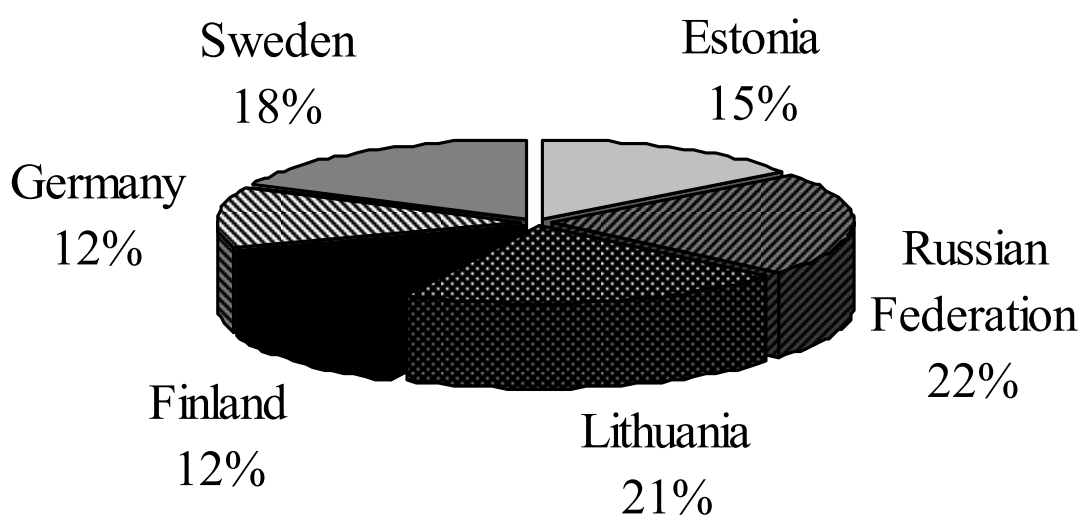

Figure 6. Main countries, from which tourists arrive in Latvia, 2010 (authors' calculations based on data from (3)).

The estimation of some indicators of tourism and travelling and its trends is important to clarify successes, shortages and challenges. The observed trends should be taken into consideration for further development of tourism as a sector, particularly for developing the sector strategies, programmes and legislative acts and documents on both the state and the local levels.

First of all, the purpose or aim of travelling of foreigners has fundamentally changed in the latest decades. The visiting friends and relatives as purpose of the foreigners' arrival to Latvia has decreased significantly from total number of visitors during the period of last fifteen years: $r=-0.95, \alpha<0.001$ (Fig. 7). Arrival for the business purposes has also decreased significantly $-r=-0.89, \alpha<0.001$. At the same time the percentage of person wishing to spend holidays in Latvia has increased substantially $-r=0.87, \alpha<0.001$. Evaluating these results, we could conclude that the trend of increasing the percentage of people spending holidays in Latvia from total number of visitors has a positive influence on development of the tourism sector. This positive influence is characterized by using hotels and other places of collective accommodation instead of using the private apartments of friends and relatives, where money for accommodation purposes is not spent. 


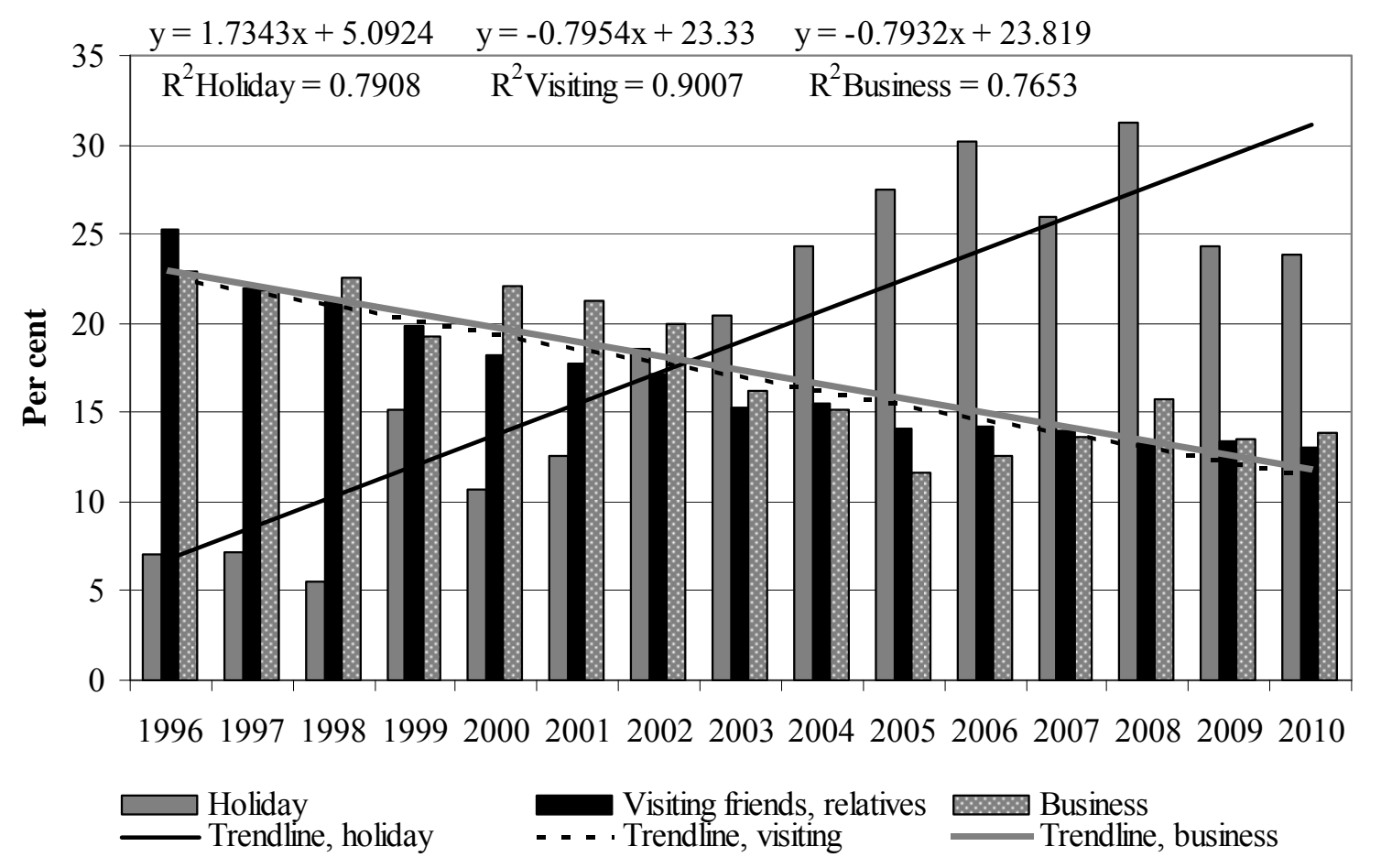

Figure 7. The trend of foreigners (per cent) crossing the border by the purpose (holidays, visiting friends, relatives, business), Latvia, 1996-2010 (authors' calculations based on data (3)).

Foreign tourists choose mainly hotels, resort hotels and motels for accommodation - 81\% (Fig. 8). This fact characterizes the legitimacy of travellers' expenses for accommodation purposes and increases revenue.

Similar establishments $8 \%$

Hotels, resort hotels and motels $81 \%$

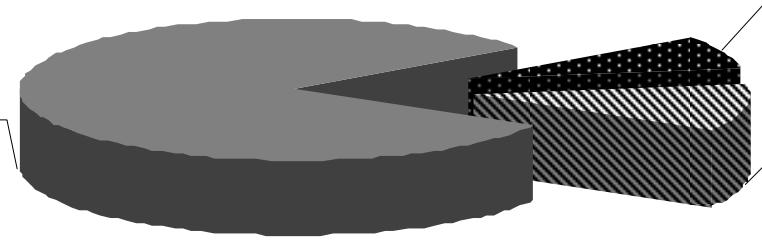

Other accommodation establishments $11 \%$

Figure 8. The type of accommodation of foreign tourists in Latvia, 2010 (authors' calculations based on data from (3))

It is important to note that accommodation of tourists (travellers) in the public or collective places of overnight staying has a positive effect on the national and local economy because of the received payments and conjoint taxes. However, this positive trend or development adversely 
affects the trend of average length of trip of foreign tourists in Latvia, which has significantly decreased during the period from 2004 to 2010.

The significance of tourist demand is well known, for example, Dwyer et al. (5) argue that the tourism demand and supply may be influenced both by price and many non-price factors (9). According to this, some, inter alia qualitative aspects, directly and indirectly connected with the tourism service, are recognized and evaluated by CSB (3). This evaluation is done in percentage by foreigners who visited Latvia. The aspects or indicators evaluated are the following: quality of services, commodity price/quality ratio, and responsiveness of people, cleanliness of towns, and entertainment possibilities and language skills of the locals. The trends of some of these aspects are presented in Figure below (Fig. 9). Only one aspect or indicator of qualitative surroundings language skills of the local people or residents - has improved during the last years. Some qualitative aspects, such as quality of services and commodity price/quality adequacy, after decreasing during economic and financial crisis, start showing signs of recovery in the recent years (Fig. 9).

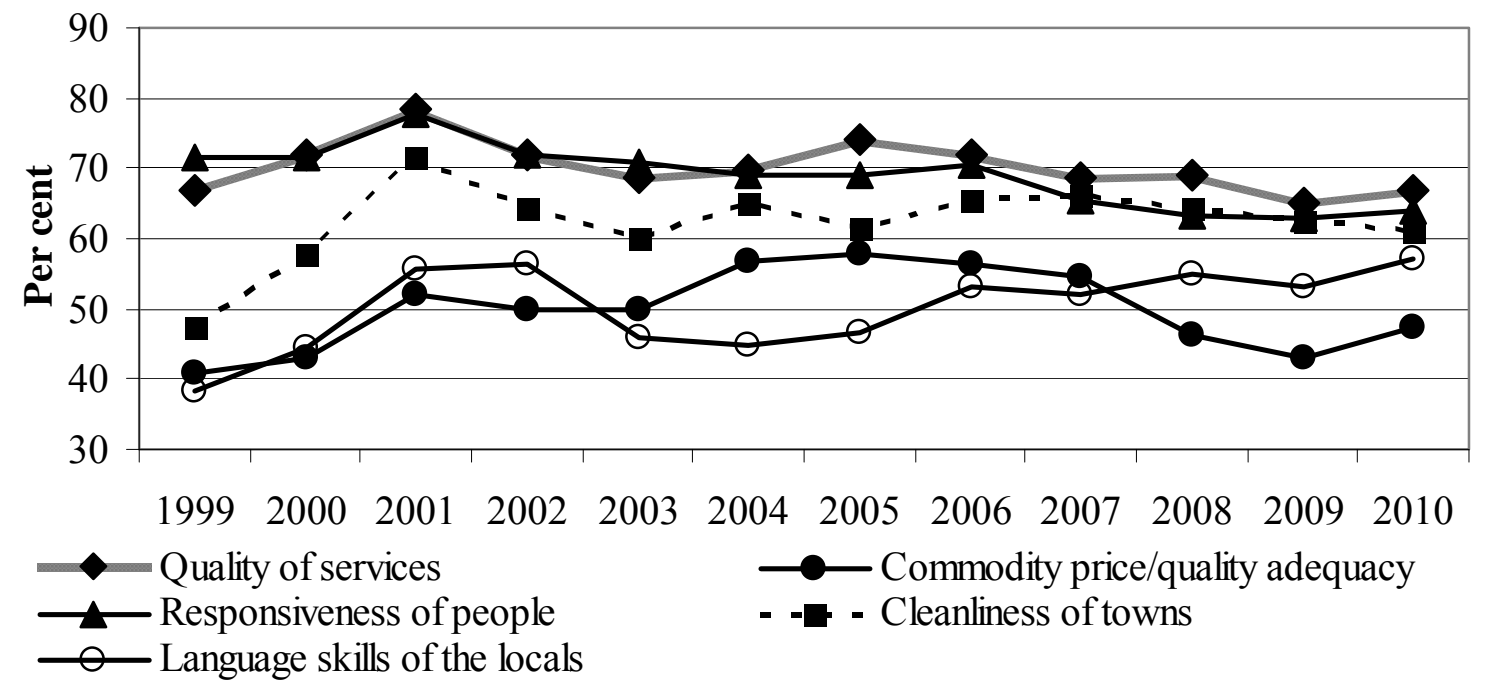

Figure 9. Results of evaluation by foreign travellers' of some aspects (per cent) of a trip to Latvia, 1999-2010 (authors' calculations based on data from (3)).

However, some important indicators as cleanliness of towns and responsiveness of people, assessed by tourists, still are showing no positive changes or improvements. Moreover, responsiveness of people has decreased by 13.7 per cent points, comparing data between 2001 and 2010. Similar results are observed, when comparing cleanliness of towns rating by tourists between 2001 and 2010, where decreasing achieves 
10.4 percent points. It means that further development of tourism or foreign tourists' visiting should be dependant not only on activities of enterprises involved in the tourism sector, but it also should depend on activities realized by related branches, municipalities and broader society for creating of favourable environment for foreign travellers and tourists.

\section{Conclusions and proposals}

Tourism is recognized as one of the most important economic sectors or industries in the world and many countries views tourism as the main instrument for economic and regional development.

Like other activities of service sectors, the tourism spending or expenditure, has direct and secondary (indirect and induced) impact or effect on the economy, and presents complex interaction. The most direct effects occur within the primary tourism sectors - accommodation, restaurants, transportation, entertainment, and retail trade etc.; and through secondary effects, tourism affects most sectors of the economy; and causes social and environmental changes.

The results of comparison of some indicators of tourism development between the Baltic States are as follows: growth of the number of tourists is significant only in Estonia, but in Latvia an opposite trend is observed - the number of tourists has decreased; evaluating long-term (1999-2010) trends of nights (1000) spent in hotels and similar establishments in the Baltic States, the growth was significant in Estonia and Lithuania, but not in Latvia; in 2011, the Baltic States, apart from Estonia, show positive trend of all holiday trips (domestic and outbound) unlike the EU average trend, moreover, Latvia is the only Baltic State which, compared to the EU average, shows positive trend or percentage change in the number of long holidays and short holidays both domestic and outbound.

The purpose or aim of travelling of foreigners has fundamentally changed during the latest decades. Visiting friends and relatives as purpose of the foreigners' arrival to Latvia has decreased significantly from total number of visitors in the period of last fifteen years. Coupled with the fact that majority (81\%) of tourists or travellers arriving in Latvia has chosen public or collective places of overnight staying, this trend has a positive influence on national and local economy due to received payments and conjoint taxes. However, this positive trend or development adversely affects the trend of average length of trip of foreign tourists in Latvia, which has significantly decreased during the period from 2004 to 2010 . 
Analyzing some qualitative aspects or indicators, directly and indirectly connected to the tourism service, and ranked by foreign tourists, we get the following results: only one aspect or indicator of qualitative surroundings - language skills of the local people or residents - has increased during the recent years; some important indicators as cleanliness of towns and responsiveness of people still show no positive changes or improvements; moreover, responsiveness of Latvia's people has decreased by 13.7 per cent points and cleanliness of towns by 10.4 percent points, comparing the data between 2001 and 2010.

Taking into account that Latvia shows great potential for further development of tourism, the importance of tourism as countries' economic sector is great in Latvia. Further development of tourism's export or foreign tourists' visiting should be dependant not only on activities of enterprises involved in the tourism sector, but should also depend on activities realized by related branches, municipalities and broader society for creating of favourable environment for foreign travellers and tourists.

In our opinion the role and potentialities of tourism sector in the economy of Latvia is not sufficiently and properly assessed and should be re-evaluated by politicians and officials.

More studies are required to help evaluating the shortages of Latvia's tourism development, compared to other countries, particularly the Baltic States.

\section{Bibliography}

1. BAGGIO, R. Symptoms of complexity in a tourism system. Tourism Analysis. 2008. Vol. 13, Issue 1, pp. 1-20.

2. BAGGIO, R., SCOTT, N., COOPER, C. Improving tourism destination governance: a complexity science approach. Tourism Review. 2010. Vol. 65, Issue 4, pp. 5160.

3. CENTRAL STATISTICAL BUREAU OF LATVIA (CSB) databases. Accessed: http://data.csb.gov.lv/Dialog/statfile1.asp

4. Components and Elements of Tourism. 2011. Accessed: http://codis4u.wetpaint.com/page/Components+\%26+Elements+of+Tourism

5. CREACO, S., QUERINI, G. The role of tourism in sustainable economic development. 43rd Congress of European Regional Science Association, 27. August - 30. August 2003, Zagreb. 17 p.

6. Definition of tourism. World Tourism Organization. Accessed: http://torc.linkbc.ca/torc/downs1/WTOdefinitiontourism.pdf

7. DEMUNTER, C., DIMITRAKOPOULOU, C. Occupancy of tourist accommodation surpasses the pre-crisis level. Statistics in focus, 2012. No. 8. pp. 1-8.

8. DWYER, L., FORSYTH, P., DWYER, W. Tourism Economics and Policy. Bristol: Channel View Publications, 2010. 776 p. 
9. EGZIABHER, M. Information Technology: Its Uses in Tourism Industry. Catering and Tourism Training Institute. Accessed: http://fama2.us.es:8080/turismo/turismonet1/economia\%20del\%20turismo /turismo\%20y\%20nuevas\%20tecnologias/information\%20technology\%20its \%20use\%20in\%20tourism\%20industry.pdf

10. Europe, the world's No 1 tourist destination - a new political framework for tourism in Europe. European Commission. Brussels, 30.6.2010, COM (2010) 352 final.

11. European Parliament resolution of 29 November 2007 on a renewed EU Tourism Policy: Towards a stronger partnership for European Tourism. European Parliament. Accessed: http://www.europarl.europa.eu/sides/getDoc.do?pubRef=//EP//TEXT+TA+P6-TA-2007-0575+0+DOC+XML+V0//EN http://epp.eurostat.ec.europa.eu/portal/page/portal/statistics/search_databa se.

13. FLECHA, A. C., FUSCO, J. P. A., DAMIANI, W. B. et al. The Economic Impacts of Tourism in Ouro Preto, MG, Brazil. Brazilian Journal of Operations \& Production Management, Volume 7, Number 2, 2010. pp. 29-46.

14. GOELDNER, C. R., RITCHIE, B. Tourism: principles, practices, philosophies. New Jersey: John Wiley and Sons, 2006. 590 p.

15. HALL, C. M. Pro-poor tourism: who benefits?: perspectives on tourism and poverty reduction. New York: Channel View Publications, 2007. 167 p.

16. HALL, C. M., LEW, A. A. Understanding and managing tourism impacts: an integrated approach. New York: Routledge, 2009. 365 p.

17. HORVATH, E., FRECHTLING, D. C. Estimating the Multiplier Effects of Tourism Expenditures on a Local Economy through a Regional Input-Output Model. Journal of Travel Research, 1999. Vol. 37, No. 4. pp. 324-332.

18. HUYBERS, T. Tourism in developing countries. Cheltenham: Edward Elgar Publishing, 2007.667 p.

19. JAMAL, T. AND ROBINSON, M. Introduction: The Evolution and Contemporary Positioning of Tourism as a Focus of Study. In: Jamal, T., Robinson, M. (eds.). The Handbook of Tourism Studies. Thousand Oaks: Sage. 2009. pp. 1-16.

20. LEJARRAGA, I., WALKENHORST, P. On linkages and leakages: measuring the secondary effects of tourism. Applied Economics Letters. 2010. Vol. 17, Issue 5. pp. 417-421.

21. MILNE, S., ATELJEVIC, I. Tourism, economic development and the global-local nexus: theory embracing complexity. Tourism Geographies. 2001. Vol. 3, Issue 4, pp. 369-393.

22. MITCHELL, J., ASHLEY, C. (2010) Tourism and Poverty Reduction: Pathways to Prosperity, London: Earthscan, 2010. 157 p.

23. NDOU, V. New Approaches for Managing Tourism Complexity: Implications and Insights. In: Lytras, M. et al. (eds.) Digital Culture and E-Tourism: Technologies, Applications and Management Approaches. IGI Global. 2010. pp. 123-138.

24. RATZ, T., MICHALKO, G. The contribution of tourism to well-being and welfare: the case of Hungary. International Journal of Sustainable Development, 2011. Vol. 14, No. 3-4. pp. 332-346. 
25. SCHEYVENS, R. Pro-poor tourism: Is there value beyond the rhetoric? Tourism recreation research. 2009. Vol. 34, No. 2, pp. 191-196.

26. SCHILCHER, D. Growth versus Equity: The Continuum of Pro-Poor Tourism and Neoliberal Governance. In: Hall, C. M. (eds.). Pro-poor tourism: who benefits?: perspectives on tourism and poverty reduction. New York: Channel View Publications, 2007. pp. 56-83.

27. SHARPLEY, R. The Myth of Sustainable Tourism. CSD Working Papers Series 2009/2010 - No. 4. Centre for Sustainable Development, 2010. 15 p.

28. SHARPLEY, R. Tourism, Development and the Environment: Beyond Sustainability? London: Earthscan, 2009. 220 p.

29. Study on the Role of Tourism in Socio-Economic Development. United Nations. New York: United Nations, 2007. 119 p.

30. STYNES, D. J. Economic Impacts of Tourism: a Handbook for Tourism Professionals. Michigan: Michigan State University, 1997. 32 p.

31. TELFER, D. J., SHARPLEY, R. Tourism and development in the developing world. New York: Routledge. 2008. 263 p.

32. Tourism Multiplier Effect. Barcelona Field Studies Centre, 2012. Accessed: http://geographyfieldwork.com/TouristMultiplier.htm

33. Uherek, E. Context: Tourism in Europe and in the world. 2008. Accessed: http://www.atmosphere.mpg.de/enid/Nr_9_July_6_Air_traffic/C_Tourism_5r w.html

34. WEGNER, A., ALLISON, H. E., TREMBLAY, P. Dealing with complexity in tourism settings: the applicability of the 'Resilient Futures Process' to the management of tourism resources. In: Carlsen, J. et al. (eds.) See change: tourism and hospitality in a dynamic world, Fremantle, Western Australia: Curtin University of Technology, 2009. pp. 1-30.

35. What is Tourism? Accessed: http://www.go2hr.ca/BCsTourismbrIndustry/WhatisTourism/tabid/71/Defa ult.aspx

\section{Kopsavilkums}

Lai gan tūrisms tiek definēts dažādi un daži autori atzīmē, ka to vispār nav iespējams definēt, Pasaules Tūrisma organizācija tūrismu definē šādi: „tūrisms personu darbības, kas saistītas ar ceḷošanu un uzturēšanos ārpus savas pastāvīgās dzīvesvietas brīvā laika pavadīšanas, lietiškso darījumu kārtošanas vai citā nolūkā ne ilgāk par vienu gadu". Lai gan plaši izplatīts un populārs ir vispārpien,emtais viedoklis, ka tūrisma nozare ir viena no svarīgākajām nozarēm gan pasaules, gan atsevišksu valstu ekonomiskajā attīstībā, tomēr nav vienotas definīcijas tūrisma nozarei. Daudzi zinātnieki uzskata, ka līdztekus tūrisma definīcijas trūkumam, eksistē nepilnības, kas saistītas ar vienotas izpratnes un vienotas metodikas trūkumu, kas apgrūtina tūrisma nozares attīstības un ietekmes novērtēšanas iespējas. Statistikas datu bāzes šādiem uzdevumiem nav piemērotas un tās var izmantot atsevišksu indikatoru novērtēšanai un salīdzināšanai.

Tūrisma nozare ir atzīta par vienu no straujāk attīstošajām un svarīgākajām nozarēm visā pasaulē, tai skaitā Eiropā (Eiropas Savienībā). Tūrisma pozitīvo ietekmi, it īpaši periodā pēc krīzes, atzīst daudzi pētnieki, politiksi, starptautiskās un regionālās institūcijas. Kā būtiski svarīgākā tūrisma ietekme tiek uzsvērta darba vietu radīšana un vietējo ekonomiku stimulēšana. Tūrisma ietekmes novērtējumam piemēro dažādas pieejas, no kurām populārākās ir saistītas ar dažādu ietekmes veidu 
izdalīšanu: tiešā (direct), netiešā (indirect) un izraisītā (induced) ietekme. Tiešo tūrisma ietekmi uz ekonomisko attīstību (valsts, reǵionālo vai lokālo) dažkārt dēvē arī par primāro ietekmi, bet netiešo un izraisīto ietekmi - par sekundāro vai multiplo. Tiešās un sekundārās jeb netiešās un izraisītās ietekmes kopums veido kopējo ietekmi jeb efektu uz ekonomiku.

Eiropas Savienības (ES) vidējie rādītāji norāda, ka ES dalībvalstis atgūstas no finansiālās un ekonomiskās krīzes negatīvās ietekmes un 2010. un 2011. g. novērojams tūrisma nozares pakalpojumu pieprasījuma pieaugums. Salīdzinot tūrisma attīstību Baltijas valstu starpā, konstatēts, ka būtiska un ticama tūristu pieauguma tendence no 2005. līdz 2010. g. ir novērojama vienīgi Igaunijā, kur korelācijas koeficients ir $r=92$, un būtiskuma jeb ticamības līmenis $-\alpha<0.01$. Lietuvā šis pieaugums ir neliels, bet Latvijā novērojama tūristu skaita samazināšanās. Līdzīga tendence vērojama, salīdzinot tūristu pavadītā laika (nakšu skaita) ilgtermiṇa (1999. - 2010. g.) izmaingas. Igaunijā un Lietuvā novērojams to būtisks pieaugums, bet Latvijā tas ir daudz zemāks un nebūtisks $-\alpha>0.05$. Latvijas tūrisma sektora pēdējo gadu (2010. un 2011.g.) izaugsmes sasniegumi ir pārliecinoši uz pārējo ES dalībvalstu un Baltijas valstu fona, jo visos īsterminga (1-3 naktis) un ilgterminga (4 vai vairāk naktis) cel̦ojumos vērojams pieaugums.

Novērtējot dažus Latvijas tūrisma attīstības indikatorus, secināts, ka, lai gan ārvalstu tūristu vidēji pavadītais laiks Latvijā no 2004. līdz 2010. g. ir būtiski samazinājies, tomēr to vidējie ikdienas tēriṇi ir būtiski pieauguši $(r=0.97, \alpha<0.01)$. Kopējais ārvalstu tūristu skaits šajā pašā laikā ir pieaudzis, bet ne būtiski ticami ( $\mathrm{r}=0.78, \alpha>0.05)$, savukārt būtiski ir pieauguši ārvalstu tūristu izdevumi Latvijā. Ārvalstu tūristi visbiežāk (81\% gadījumos) apmetas viesnīcās un motelı̆os, kas ir legāls apmešanās veids un labvēlīgi ietekmē valsts budžetu. Visvairāk tūristu Latvijā ierodas no Krievijas Federācijas, Lietuvas, Zviedrijas, Igaunijas, Vācijas un Somijas. Šì informācija būtu jān,em vērā, plānojot dažādas aktivitātes valsts, pašvaldību un uzṇēmumu līmenī. Pozitīva tendence novērojama, vērtējot mērḳu, ar kuriem Latvijā ierodas ārvalstnieki, izmaiṇas. Būtiski palielinājies to tūristu skaits, kuri iebrauc brīvdienās atpūsties, bet būtiski samazinājies to iebraucēju skaits, kas apciemo radus un draugus. Tas nozīmē, ka vairāk tiek izmantotas apmaksātas kolektīvās apmešanās vietas. Ārvalstnieku novērtējums, vērtējot tūristu vides kvalitatīvos aspektus, liecina, ka laikā no 1999. līdz 2010. g. uzlabojies vietējo iedzīvotāju svešvalodu zināšanu līmenis. Pēc straujā krituma krīzes laikā adekvātāka kḷuvusi pakalpojumu kvalitātes un cenas attiecība, bet iedzìvotāju laipnība un pilsētu tīrība arvien samazinās. Salīdzinot 2001. g., kad tika novēroti visaugstākie rādītāji, ar 2010. g., konstatēts, ka iedzīvotāju laipnība un atsaucība pazeminājusies par 13.7 procentpunktiem, bet pilsētu tīrība - par10.4 procentpunktiem.

Turpmākā Latvijas tūrisma attīstība daudzējādā ziṇā būs atkarīga ne tikai no tūrisma nozarē darbojošos uzñēmumu darbības, bet saistīto nozaru, pašvaldību un plašākas sabiedrības iesaistīšanās tūristiem labvēlīgas vides radīšanā. 